\title{
ECUMENICAL AND INTERCULTURAL LEARNING - THE COMPLEMENTARITY OF TWO LEARNING DIMENSIONS
}

\author{
Wolfram Weisse \\ Centre for Contextual Hermeneutics \\ University of Stellenbosch
}

\section{Introduction}

Old problems cannot be solved with new terminology. It may, however, well be that new facts and developments also require a new vocabulary in order to describe reality adequately or to formulate objectives in current idiom. The term 'intercultural/interreligious learning' seems to be such a new key term in the educational discourse. It also recurs in the discussion of religious education in the Federal Republic of Germany, whereas 'ecumenical learning', which was introduced in the seventies and was very popular in the eighties, seems to have receded into the background. Could one, in the light of these developments, perhaps do without the term 'ecumenical learning' and merge it with the concept 'intercultural/interreligious learning'? ${ }^{1}$ The fact that intercultural learning plays a role in ecumenical learning, and dimensions of ecumenical learning appear in intercultural learning, speaks in favour of a merging of the two terms. The development from ecumenical to intercultural learning is thus implied by these terms. What they have in common is, inter alia, that both distance themselves from an accumulative, content-oriented learning in favour of an open, dialogue-oriented understanding of learning.

I find it, however, still necessary to consider the specific concerns of the two terms thoroughly and to contrast them productively with each other. I wish to argue that the priorities of the recognition of international, Christian, and religious perspectives, which are in a special way embodied in the term ecumenical learning, are supported by the retention of this term and ought to be seen in a productive interaction with 'intercultural learning', which envisages an intensification of intercultural exchange and brings the socio-environmental perspective in a regional/national context to the fore,

In order to explicate this thesis, it is essential to recollect the main aims of ecumenical learning and to examine why it could not, in the long run, survive as sole objective. Furthermore, the main aim of intercultural learning must be examined. It seems to be necessary then to make the necessary distinctions by examining very different forms and functions of this learning dimension in schools and society.

In the concluding part of this paper, I will attempt to show to what extent the approaches of ecumenical and intercultural learning should not be played off against each other, but rather be seen as complementary. 


\section{Ecumenical learning}

The much-quoted dictum of Ernst Lange: "The ecumenical experience is a threshold of current piety. Beyond this threshold there is no turning back", ${ }^{2}$ has always been more petitionary than descriptive. Today it appears increasingly as an invocation and essential admonition in a situation in which, in the face of fundamental problems and increasingly complex questions, a tendency is apparent where people revert to simple answers, to their immediate environment and to their (apparently) own problems.

This tendency of self-restriction is supported by a common variety of 'postmodernism', which JB Metz castigates with the following poignant and impressive words:

"An everyday postmodernism of the heart is unfolding; it moves the poverty and suffering of the so-called Third World back into a faceless distance. The European spirit prefers things to be 'smaller'. A new dream of innocence seems to have taken hold of European thinking. It can be found in a preoccupation with romantic and mythological themes, which can be narrated while turning one's back on a history characterized by suffering and death. The new European spirit appreciates the ethical and political suspension ... this is the way the spiritual strategies go about to immunize Europe; this is the start of the intellectual preparation of a political and cultural apartheid ideology in Europe."

Forces against this tendency must be strengthened; and in the field of education, especially in religious instruction, this undoubtedly includes 'ecumenical learning'. But what is ecumenical learning? ${ }^{4}$

Within the world-wide church, the term 'ecumenical learning' was used for the first time during the General Assembly of the ECC (Ecumenical Council of Churches) in Vancouver in 1983. The Secretary-General of the Ecumenical Council of Churches, Philip Potter, in a policy address, outlined his understanding of Church, which he characterized as a 'community of learners'. He criticized a traditional understanding of learning as the acquisition of knowledge or intellectual qualification in a formal sense, and proposed the following definition:

2 E Lange: Das ökumenische Unbehagen. In: E Lange: Kirche für die Welt. Aufsätze zur Theorie kirchlichen Handelns. München 1981, p. 307; quoted e.g. in EKD Arbeitshilfe Ökumenisches Lernen. Grundlagen und Impulse. Gütersloh 1985, p. 12.

3 Cf. JB Metz (ed.) Das Christentum und die Fremden. Perspektiven einer multikulturellen Religion, in: F Balke et al. (eds.) Schwierige Fremdheit, Frankfurt 1993, p. 217-228, quotation on p. $227 \mathrm{f}$.

4 On the topic intercultural learning see: Wolfram Weiße: Ökumenisches Lernen: Möglichkeiten und Grenzen einer neueren pädagogischen Dimension, in: Ökumenische Rundschau 38 (1989), p.181-199. Cf. G Orth: (ed.): Dem bewohnten Erdkreis Shalom. Beiträge zu einer Zwischenbilanz ökumenischen Lernens. Münster 1991. Cf. K Goßmann/ A Pithan/ P Schreiner (eds.): Zukunftsfähiges Lernen? Herausforderungen für ökumenisches Lernen in Schule und Unterricht, Münster 1995. Cf. R Koerrenz: Ökumenisches Lernen, Gütersloh 1994. Cf. K Piepel: Lerngemeinschaft Weltkirche. Lernprozesse in Partnerschaften zwischen Christen der Ersten und der Dritten Welt, Aachen 1993. On the question of ecumenical and intercultural learning, cf. R Schlüter (ed.): Ökumenisches und interkulturelles Lernen. Eine theologische und pädagogische Herausforderung. Paderborn/ Frankfurt am Main 1994.

On the entire topic of intercultural education, also in connection with ecumenical learning, see the detailed overview of Werner Haußmann: Interkulturelle Erziehung: Kontouren eines 'neuen' Bildungsprinzips in Erziehungswissenschaft und Religionspädagogik. In: R Kirste/ P Schwarzenau/U Tworuschka (eds.) Religionen im Gespräch. Engel - Elemente - Energien, vol. 2, Balve 1992, p. 158-196. 
"Learning is that personal process through which one can taste the grace of God... In the Bible, learning is a process in which people develop a relationship with God and his way of truth, justice and peace, so that they may follow this way obediently in their relationships with one another, and make it known to all nations."

This definition of learning, which Potter qualifies with the attribute 'ecumenical', contains individual, social and international elements. Ecumenical learning is a process; it is characterized by a personal perception of the grace of God; it requires understanding and obeying God's truth, his justice and his peace. This learning process is applicable to groups, societies and nations.

Christian action groups and ecumenically-engaged individuals in Germany had already used the term 'ecumenical learning' to describe their work and their aims before Philip Potter made his statement. ${ }^{6}$ In conjunction with the Secretary-General and the Education Bureau of the ECC, they prepared the way for the publication of a manual by the EKD (Evangelical Church in Germany) in 1985 with the title Ökumenisches Lernen. Grundlagen und Impulse. ${ }^{7}$ As far as quality and style (theoretical and practical sections) are concerned, it is the most comprehensive and authoritative exposition of ecumenical learning in Germany. Just like Potter, the manual regards this term as having a fundamental dimension. More than Potter, it emphasizes that ecumenical learning should not become an additional field of the church but rather, as the study emphasizes, that 'ecumenical learning is a dimension of all educational work of the church"8 The manual mentions the following five characteristics of 'ecumenical learning':

- Ecumenical learning transcends boundaries. It transcends the boundaries of origin, biography, the own possibilities of individuals and communities...

- Ecumenical learning is action-oriented. It is not satisfied with information, but wants to prepare Christians for action...

- Ecumenical learning is social learning. It is aimed at bringing about a relationship with that which is different, which is distant and foreign.

- Therefore the ability of the Christian community to forge relationships and create community is in the foreground. At the same time, ecumenical learning is associative learning. Its aim is to enable people to recognize global aspects in local situations, to discover that which is foreign in one's own life situation...

Cf. Philip Potter, Bericht des Generalsekretärs, in: Bericht aus Vancouver 1983, Frankfurt a.M. 1983 , p. 218 f:

6 Cf. Ulrich Becker, Ökumenisches Lernen. Überlegungen zur Geschichte des Begriffs, seiner Vorstellung und seiner Rezeption in der westdeutschen Religionspädagogik bis Vancouver.1983, in: Glaube im Dialog. 30 Jahre religionspädagogische Reform. HB Kaufmann zum 60. Geburtstag, Gütersloh 1987, p. 247f. For further literature and on the wide range of topics which are included in the term 'ecumenical learning', see the documentation by G. Orth: Im Horizont der Einen Erde. Kommentierte Literaturdokumentation zu Ökumene und Ökumenisches Lernen. Münster 1989.

7 Cf. Ökumenisches Lernen. Grundlagen und Impulse. Eine Arbeitshilfe der Kammer der Evangelischen Kirche in Deutschland für Bildung und Erziehung. Published by: Kirchenamt der Evangelischen Kirche in Deutschland, Gütersloh 1985. 
- Ecumenical learning includes intercultural learning. It wants to promote communication between individual cultures, traditions and ways of life...

- Ecumenical learning is a holistic process: social learning and religious learning are not separated, but form a unity...9

Ecumenical learning could in the seventies and eighties have been understood against the background of a situation teeming with problems, both world-wide and local, political and social, economical and ecological, for which there were no quick and clear-cut solutions. The Theory of Dependence which, in the seventies, provided a world-wide explanatory model for wealth, poverty, militarism and suppression, had lost its monopoly and had to make way for the insight that problems sometimes only really begin if internal conflicts and paradoxes are perceived. Therefore, Christians in the Third World formulated their misgivings about this oversimplified model. ${ }^{10}$ Even for the situation in Europe, it has emerged that the boundaries between beneficiaries and victims of our system cannot always be clearly drawn. In this transition phase, it seemed impossible even for educationists or for theologians and the church to compile joint drafts to grasp reality. This state of affairs is probably important background information to emphasize the church as a community of learners. Such a situation demands a fundamental reflection on the life-giving roots of the faith, and a realistic consciousness of not being lords of the world, neither politically nor theologically. This is perhaps a painful realization, but it also provides relief and facilitates new insights. In this situation, the ecumenical horizon becomes meaningful for the community of learners. This may promote the perception that problems which are present all over the world can be analyzed more easily through global co-operation, and in this way solutions can be found. The ecumenical horizon, however, also demands the much more important learning process: that people in other parts of the world are involved in a different stage of development, which one may already have encountered or which lies ahead. This provides possibilities for interpretation and advance planning. Christians have to recognize, as never before, the diversity of Christian churches today with their differences in spiritual life and identity. Furthermore, the ecumene as a community of churches offers a multitude of thoughts and experiences on the way to church unity and theologically-founded engagement on the social and political terrain.

The discourse of ecumenical learning has developed in two directions. On the one hand, ecumenical learning has become important for the endeavours of the ecumenical Conciliatory Process of Justice, Peace and the Integrity of Creation. In its approach, which corresponded to the aims of the Conciliatory Process, ecumenical learning wanted to open up and support an essential international learning process for all people, to attempt to resolve, on a global level, problems, which threaten the survival of mankind. On the other hand, the term was divorced from its Protestant base and also taken up by the Catholic church, for example. " Furthermore, on the basis of an additional definition of ecumene, its meaning was extended to include other religions

9 Cf. loc.cit., p. 17.

10 Cf. MM Thomas, quoted in Paul Albrecht: From Oxford to Vancouver. Lessons from fifty years ecumenical work for economic and social justice. In: $E R 40$ (1988), p. 147f., especially p. 163.

11 Cf., for example, Ökumenisches Lernen - ökumenische Überlegungen und Vorschläge. Ein Studiendokument der Gemeinsamen Arbeitsgruppe der römisch-katholischen Kirche und des ökumenischen Rates der Kirchen. In: Ökumenische Rundschau 42 (1993), p. 487-495. 
and ideologies. ${ }^{12}$ The global socio-ethical orientation and the widening of the horizon beyond the Christian faith strengthened the term 'ecumenical learning'. and extended the group which it was meant to reach. This still could not prevent it from being increasingly marginalized in the German discourse. The main reasons for this can be found in two dangers which were inherent in the idea of ecumenical learning.

The one danger was that the expectations of ecumenical learning were too high, when it was characterized by five, in themselves rather demanding, categories such as 'transcending boundaries', 'action-oriented', 'social learning', 'intercultural learning' and 'learning as a holistic process'. The second danger seemed to be more serious. High ambitions run the risk of being reduced to slogans. The listing of these attributes contributed towards covering up the difficult problems and aims which are, for example, connected with action-oriented learning. Furthermore, the quick acceptance of, for example, intercultural or holistic learning implied that one already knew what that was or how it worked. To put it briefly, there was the danger of overloading and silently playing down the meaning of these concepts. The one meant overestimating the possibilities of ecumenical learning, and had to lead to disappointment; the other meant playing down the problems and facts, which first needed to be recognized and analyzed in depth before they could become permanent characteristics of learning.

Both dangers have placed a strain on the term 'ecumenical learning' and have played a part in marginalizing it. ${ }^{13}$ Furthermore, it also lost its appeal, especially after the time when almost every topic in religious education was discussed under the heading of ecumenical learning. Two things, however, were decisive in marginalizing the term: on the one hand, the world situation became less transparent and more paradoxical after the collapse of the Soviet Block in 1989, and the strong internationial dimension of ecumenical learning became a rather demotivating point of reference. On the other hand, there were many problems within a national/local context which required urgent solutions. In the face of increasing animosity towards foreigners, which also appeared in Germany after 1989, it seemed essential to be concerned with dialogue in one's own context; and so the term 'intercultural communication' became the focus of attention.

\section{Intercultural and interreligious learning}

Intercultural and interreligious learning is aimed at communication within multicultural societies. ${ }^{14}$ It focuses on culturally-based differences in life situations and wants to utilize these for mutual enrichment. This became a topic in Germany only with the increase in the immigration of migrant workers, refugees and asylum seekers from other countries, and with the realization that Germany has a multicultural (and, what is less apparent, multireligious) population. This has been under discussion for approximately 15 years. The approaches towards intercultural learning, which

Cf. KE Nipkow: Ökumenisches Lernen - Interreligiöses Lernen - Glaubensdialog zwischen den Weltreligionen. Zum Wandel von Herausforderungen und Voraussetzungen. In: G Orth (ed.): Dem bewohnten Erdkreis Schalom... Münster 1991, p. $301 \mathrm{f}$. See also the paper by K Raiser (at present Secretary-General of the ECC): Ökumene und Lernen - nur ein Problem der Didaktik? In: G Orth (ed.): Dem bewohnten Erdkreis Schalom, Münster 1991, p. 171-178.

14 Cf. the bibliography and collection of material: C Scheilke/P. Schreiner (eds.): Interkulturelles Lernen. Zeitschriften, Aufsätze, Bücher. No. 12 in the series 'Im Blickpunkt'. Literaturhinweise und Texte zu aktuellen Themen, Comenius-Institut, Münster 1993. 
developed in this relatively short period of time, took place in three phases. ${ }^{15}$ Initially, it referred to the learning requirements of foreigners in their adaptation to the German language and culture. This aim was expressed with the term 'foreigner education' (Ausländerpädagogik). In the second phase, it was realized that native citizens were also learners who were learning a foreign culture. The immigrants become 'objects' of learning. In the third phase, an understanding of intercultural communication of learning consisted as dialogue came to the fore. This is a learning process in which different cultures take part, critically. reflecting their own historically developed background. This path, which led from the foreigner education within the field of general education to mutual intercultural communication, had its parallel in religious education: From the study of foreign religions developed the perspective of interreligious dialogue with its reciprocating nature.

In the meantime, both intercultural and interreligious learning have become wellestablished terms. But even they are endangered. On the one hand, they are in danger of becoming rather woolly terms by being applied to all sorts of topics and fields of education. The educationist, Renate Nestvogel, ascertained the following: "The use of the term intercultural learning had become inflationary. It includes almost everything from pre-primary- to adult education." ${ }^{16}$ In addition, the term is also being played down subconsciously by suggesting that through intercultural communication and a widening of horizons, the communication between representatives of different cultures would be successful, as long as a little goodwill prevailed. Moreover, the term intercultural learning can cover up the inherent challenge that intercultural learning can be something quite different, depending on the group of learners. Furthermore, intercultural learning, with its emphasis on cultural encounters in a local context, might not be able to assess problem areas adequately. These can only be resolved from a larger international, intercontinental or global perspective. Finally, the topic of religion - as is the case in the general educational discourse in Germany - has been almost completely marginalized in view of the topic of intercultural learning.

In the following passage $\mathrm{I}$, by discussing the ambivalences and different forms of this term, would like to contribute towards clarifying and outlining intercultural learning in more detail. The claims I make are not comprehensive, nor is the passage on ecumenical learning. ${ }^{17}$

Let us return to a not atypical description of intercultural learning for the field of religious education in a church context. This can be found in the EKD-manual mentioned above and reads as follows:

"Intercultural learning ... wants to promote the communication between individual cultures, traditions and ways of life because only the widening of one's horizon to Dritten Welt, Frankfurt/Main, 3rd edition 1994, p. If. 
encompass the diversity of the church all over the world, and also the diversity of life on this earth, lets one experience and recognize the wealth of creation (nature, history and culture)." 18

This definition seems to be too simple, a) in view of the potential difficulties and the necessity of reflecting on cultural parameters, b) as it is too closely oriented according to the congregational perspective and ignores the reference to the school, and c) as it does not refer to the interrelationship between intercultural/interreligious learning and. ecumenical learning. These three points will be discussed in the following section.

\subsection{Ambivalences of intercultural learning and the required reflection of social parameters}

At this point, I would only like to mention two points which, in view of the definition of intercultural learning quoted above, give rise to more questions than they provide answers. On the one hand, the idea of a 'broadening of one's horizon' through contact between cultures is a simplification of intercultural communication in as far as it disregards the possibility of conflict through contact with other cultures. Conflicts and differences, also those which cannot be solved quickly or not at all, should be taken into account by the definition of intercultural learning, if it is not be reduced to the harmless variant of a tourist brochure, which sees foreigness in folklore. On the other hand, the question must be asked whether intercultural learning is not a futile compensatory exercise which tries to address the increasing social/economic differences between the cultures in the field of education. ${ }^{19}$ If this were the case, intercultural education would shroud the necessity of changing dominant political parameters.

This makes it necessary to reflect on social parameters in order to be able to transfer intercultural learning - with its objective of widening perspectives and creating mutual understanding - adequately within a context.

As an example, I refer to the context of South Africa which from a distant, 'foreign' German perspective reveals two things: the interconnection of intercultural learning with the political system, as well as the socio-political priorities and the difficulties to comprehend intercultural learning unambiguously. The first point appears clear regarding the Republic of South Africa.

The system of apartheid was aimed at separation on all terrains, including church and school. That is known to us. However, less known to us is the fact that in the basic policy of apartheid (Eiselen), separation was based on the idea that the different races should be respected within their different cultures, and that one group should not be dominated by another. The good intention to make it easier for every population group to maintain its own culture was, however, perverted in that the cultural differences, within a framework of political oppression, very soon became rather a sign of privileged or underprivileged status. Against the background of South African experiences, one should be mindful of concepts which aim at providing possibilities for the preservation of cultural identity without taking into consideration the economic or socio-political framework. 
The consequences for education in present-day South Africa, which are based on the experiences of the past 50 years, can be formulated in a nutshell: The 'old forces' in South Africa want separation which provides them with the freedom to continue with their old approach; the 'new forces' want one school system for all, irrespective of race or religion. These differences are apparent in statements concerning religious instruction. At the same time, they show the difficulty to define intercultural learning clearly. I would like to demonstrate this with two examples.

The leader of the Conservative Party, Andries Treurnicht, a white reformed theologian, said the following during an interview in February 1993:

"I think a young child should, first of all be ... immersed in that which is his own background and his own ... religious principle, and not be educated in a sort of multi-religious set-up where he doesn't belong anywhere. Well, I would suggest it takes quite some time for a youngster to grow into his own cultural set-up. He should not be confused before he is confronted with people who have other religious views."

To the question from what age communication with other convictions should take place, Treurnicht replied:

"When they are at university and have a more open-ended approach to life and all its problems, then the foundation must be as firm as possible." 20

The spokesman for the ANC, Carl Niehaus, also a white reformed theologian, held a different view during an interview, also in February 1993:

"Religious education which introduces people to their specific faiths is a matter for the churches. Religious education in schools, however, will have to contribute towards a dialogue between different religions... But one of the things I would like to see emphasized is religious tolerance..."21

The contrast is clear: On the one hand, there is a defence against intercultural and interreligious learning situations so that one can develop a definite identity in a homogeneous environment; on the other hand, there is a vision of dialogue and tolerance in a joint, integrated education system, open to all population groups. On the one hand, the respective own culture is prescribed; on the other, priority for dialogue and tolerance.

In view of our discussion of intercultural religious instruction, the following can be said: Despite considering all possible justification of a plea for religious education within a homogeneous environment, the question should be asked whether this approach - in as far as it concerns religious education at schools - does not directly or indirectly serve the stabilization of specific interests.

To differentiate this question further, I would like to add the following in view of South Africa: Religious educationists in the country (amongst others Gordon Mitchel1 $1^{22}$, who belong to the 'new forces' and support the position of $\mathrm{C}$. Niehaus, are considering whether groups which have been oppressed in the past should not, at least

21 Cf. W Weiße: Dialog, Religion und Toleranz. Interview mit Carl Niehaus. In: EPK, loc.cit., p. $32 f$.

22 Cf. I Lohmann/W Weiße: Einleitung. In: ibid., loc.cit., p. XV-XXVI. 
for a transition period, receive their (religious) instruction in a homogeneous class setting, if this could provide clarity on an own cultural and religious position, in as far as it had been moved to the periphery in the past decades.

Intercultural learning provides a sense of community. It could, none the less, be necessary to have separation, at least for a limited period; this, however, could lead to a dangerous manifestation of the status quo. The question of an appropriate construction of intercultural learning can, therefore, not be answered without taking into consideration the historical and socio-political situation. It is generally difficult to find an answer. Here the vision of ecumenical learning as an international community of learners can be an important means of countering continuous separation and the arrogant expectation of learning through personal encounters.

\subsection{Interreligious learning within the context of (religious) instruction at school}

Another paper in this issue of Scriptura describes which approaches to and forms of learning are possible in religiously- and culturally-diverse classes. ${ }^{23}$ It has become clear that pupils generally only have an interest in religious instruction if it is relevant to their own life situation and if it facilitates an exchange of different points of view and opinions in such a way that the pupils can take part in lively discussions, exchange different experiences and form their own opinions of religio-cultural topics. Such a life-oriented approach does not imply that pupils continuously talk about their own experiences. Rather, as is the case with all tuition, careful planning is necessary in conjunction with the pupils, and the importance of reading stimulating and informative texts should not be underestimated. Such texts should not precede the pupils' experiences, but the two should be related to each other. Not only for the pupils but also for the teachers, the presence of different cultural and religious points of view can be an enrichment. If limitations and dangers are also perceived during periods of instruction, then such a time of interaction can be perceived as an enriching experience by all participants.

However, structural differences may also be perceived, which require internal differentiation concerning the question of dialogue in heterogeneously-composed classes. Of considerable importance for the possibilities and effects of religious instruction based on real life situations, is the structure of the residential area which the school serves. In our empirical research, we found that the possibilities for exchange during religious instruction are extremely fruitful in instances where the schools were situated in the areas of Hamburg in which the population of different cultures, religions, languages and (sometimes) nationalities lives together in a pleasant atmosphere and where a good infra-structure with shops, restaurants, pubs, recreation facilities and small businesses facilitate the co-existence of the different groups of the population. On the other hand, however, the objectively- and subjectively-observed meaningfulness of exchange among pupils is reduced if their schools are situated in residential areas where the communities are at loggerheads with one another. Here the exchange is limited to the periods of instruction and is not related to the prospect of

23 On the forms of religiousness of pupils as well as the priorities in their attitude towards religious education, cf. the contribution by F-O Sandt and W Weiße in this issue of Scriptura. On the experiences and evaluations of teachers in multireligious groups, cf. T Knauth and W Weiße in this issue of Scriptura. 
carrying a growing understanding between, for example, Germans and Turks - and on religious terrain, it means between Christians and atheists or Muslims - from the school into everyday life. Where, for example, Turks live in parts of Hamburg from which 'Germans' have separated themselves, interreligious and intercultural dialogue would have a different meaning and - we still have to research that in more detail would have to be approached and applied differently than in parts of the city where members of different cultures and adherents of different ideologies and religions live together harmoniously.

Interculturally-oriented religious education has to take on a completely different form in classes where pupils are relatively homogeneous as far as language, culture and religion are concerned. The necessity of interreligious communication is not brought about by the composition of the class, but has to be seen in a wider context of education in our society which can no longer do without a larger intercultural dimension, cannot do without dialogue between the various cultural and religious positions. ${ }^{24}$

In situations where classes are relatively homogeneous, it is essential to arrange real life encounters with persons of other cultures and religions. It is also more important than in a heterogeneous class to read and discuss texts in class in which positions other than those present in the class are reflected.

To make real encounters possible, it is, therefore, essential to invite dialogue partners of other religions into the class or, otherwise, to leave the school building with the pupils to make an interreligious encounter possible 'in loco'. Both possibilities are time-consuming, but well worth the effort. The visit of a Muslim woman to a class will be much more impressive and realistic for the pupils than the usual teaching situation. The relation of an orthodox Christian of German origin from Kazakhstan, who describes his faith with the help of an icon will generally be more vivid than a text; and the importance of religion for someone who has moved into a different political/cultural context can become more evident during a discussion than through an analysis. Visiting a church, a temple or a mosque will open the pupils' eyes for the relationship between district, culture and religion. Such steps are necessary, and they will become more important as schools undergo reforms which increasingly emphasize learning through encounters and experience. They can, however, not structure all tuition.

This emphasizes the necessity for teaching materials which make it possible to create an awareness of other religions and cultures in a homogeneous class. Most of the teaching materials used in our schools up to now are, none the less, problematical. On the basis of a predominantly Western science of religion, they convey information about the subject matter 'foreign religions' and 'world religions'. This approach is problematical in two respects. On the one hand, it is far removed from a reference to the real world and usually creates the impression amongst the pupils that it is a system, which one can learn by heart for the next test, but which is both far removed from life and uninteresting. On the other hand, and this point weighs more heavily, such formalizations often create an artificial scheme of 'Islam', 'Christianity' or 'Buddhism' which neither recognizes the diversity of these religions, nor the selfawareness of the people who regard themselves as members of these religious 
traditions. It is, therefore, pedagogically as well as theologically problematical to try to discover the convictions and faith of people by means of a system of ideology or religion. Rather, it appears appropriate to approach religion from the point of view of an everyday experience. Such an approach must also be evident in the teaching materials. In Germany, there is a tremendous deficit in this field. From Great Britain, for example, a great deal can be learnt as far as the development of religio-pedagogical material is concerned. In Coventry/Warwick ethnological methods were employed in a long-term study which examined the lives of children in a multicultural context. On this basis, teaching materials were developed which reflect the life of individual people with Christian, Hindu, Moslem or similar backgrounds in a multicultural society and school. ${ }^{25}$ This material does not aim to generalize, but rather to provide examples and to bring different life styles together in view of the similarities at school, in society and recreation, but also incorporating different cultural and religious backgrounds and applying practical religiousness. One would have to investigate the development of similar teaching materials in our field, which are not just based on teaching systems, but rather are a reflection of concrete life situations of children and the youth in a multireligious society. Religious education would have to follow an approach which seems to be well-founded and theologically appropriate against the background of ecumenical theology and corresponding experiences. in interreligious dialogue. ${ }^{26}$

Different approaches to interreligious learning will have to be followed according to the composition of the respective classes. These approaches are supplementary of and complementary to one another. Even in a multi-religious class, work with texts is essential, visits are useful, but dialogue in the class context creates new possibilities for the organization of the classes. On the other hand, the possibility of discussion will also exist in a relatively homogeneous class, in which pupils can make contributions with their own personal experiences, so that different priorities and anticipations, based on similar backgrounds, can lead to lively interaction. The input concerning other cultures and religions will have to come from the teacher.

Intercultural learning in schools will have to follow different approaches according to the composition of the classes and according to the social situation and structure of the respective part of the city, and it can take place in completely different ways, even if the aim is always the same.

Intercultural learning thus has to take into account the different social conditions and the composition of the body of pupils in order to be able to find appropriate ways in which to recognize and approve of the multicultural nature of our society. As far as schools are concerned, and empirical studies in Hamburg have established this, cultural exchange amongst pupils and communication between different religious and ideological positions is appreciated. 


\section{Conclusion and Rèsumè}

Despite the importance of intercultural learning, it should not take the place of ecumenical learning. According to my opinion, the larger parameter of ecumenical learning provides the necessary framework for intercultural learning, which has the advantage of being oriented towards real life situations, but the danger of being limited to the context of own experiences.

In view of the attractive and difficult elements of intercultural learning

- problems of people in other countries, especially Third World countries, could be ignored

- people's answers to problems, which we have caused or by which we are also affected, might not even be discussed

- expectations of people in other parts of the world, especially expectations in the view of hopeless conditions, may not even be recognized by us, and cannot serve as an encouragement when we ourselves are in situations which we regard as hopeless.

These dimensions have been touched upon within the framework of ecumenical learning, dimensions which aim at man's responsibility in a world-wide sense, a responsibility which can be born in the Jewish-Christian tradition by the central hope of the Kingdom of God. ${ }^{27}$

That these expectations can, for example, refer to the past and present of the ecumenical movement, i.e. to reflective processes, to successful and unsuccessful experiences, to theological disputes, and the many-faceted regional approaches which reflect the basic questions in very different ways, gives them a concrete point of reference with a rich potential and a background which may dampen arrogant or high hopes for quick solutions, as well as curtail increasing self-centredness or resignation which attributes success, or failure, only to the own person or group.

\section{Rèsumè:}

\section{Summary of main points on Intercultural Learning - Ecumenical Learning}

1. The term 'intercultural learning' has become popular during the past few years. There are very good social and - as far as intercultural learning in religious education is concerned - theological and pedagogical reasons. However, intercultural learning cannot replace ecumenical learning. The strong points of both approaches complement each other sensibly and necessarily.

With reference to ecumenical learning, intercultural learning must be analyzed and differentiated in more detail than has been done up to now. Ecumenical learning, with its claim to being a world-wide international Christian approach, must be preserved and utilized within the specific aims of intercultural learning. Conversely, the basic aim of intercultural learning provides the necessary impulse for the serious study of the possibilities and

27 Cf. W Weiße: Ökumenisches Lernen und Erneuerung der Kirche. Lernimpulse aus der Geschichte der ökumenischen Bewegung. In: R Schlüter (ed.): Ökumenisches und interkulturelles Lernen, loc.cit., p. 67-85. 
difficulties of learning processes in one's own society in which a multiplicity of cultures, religions and ideologies exist.

2. Despite the urgency and relevance of intercultural learning, one may not overlook the fact that neither the functions nor the forms of intercultural learning are very clear.

- The demanding aims of intercultural encounters and understanding may, within a social context in which there is increasing division, i.e. domination by one group, suppression of another, appear to be a futile compensation for problems which must be solved on a political rather than on a pedagogical level. Conversely, it also appears inappropriate to underestimate the potential contribution of education towards social tolerance and intercultural, as well as interreligious, understanding.

- Historical presuppositions, as well as cultural and economic disparities in a society, must be considered so that apparent concessions to an unhindered, 'homogeneous' existence of different cultures does not furtively lead to sort of apartheid. Special situations (e.g. when minorities, who have been oppressed by society for a long time, have to rediscover their identities) may sometimes speak in favour of allowing intercultural learning to take place within separate 'homogeneous' groups of learners.

- Intercultural learning has to be adapted to the specific group of learners. Therefore, form and method will vary greatly from, for example, culturally or religiously homogeneous to heterogeneous groups of learners.

3. For pupils - and for teachers - (religious) instruction, where different cultural and religious points of view are articulated by the participants, is more interesting than tuition in 'homogeneous' groups of learners (based on empirical study in Hamburg), where different points of view are experienced only indirectly. Positions, based on personal life situations, are more interesting than a dogmatic text.

The structure of the part of the city in which a school is situated and in which the pupils live, plays an important role in the approaches to and scope of interreligious exchange in heterogeneous groups of learners. In homogeneous groups of learners, real-life situations must be created and suitable materials developed, in order to show religiousness within biographically concrete lifesituations.

4. In the general pedagogical discourse in Germany, the importance of religion in intercultural learning is generally not recognized, or not regarded as important. In view of the far-reaching claim of ecumenical learning, the importance of interreligious learning and of religious factors for intercultural learning must be examined more closely. This is also in line with the interests of many 'foreign' pupils, who generally regard religion as much more important for themselves than their German counterparts.

5. Together with the possibilities of interreligious and intercultural learning, there are a number of fundamental questions which must still be answered satisfactorily. This includes, for example, the importance or form of dialogue or interaction in the classroom which aims at intercultural learning. Such 
considerations should make use of experiences and deliberations in the fields of general education, philosophy and ecumenical theology.

6. Present-day religious education must be intercultural as well as ecumenical. Intercultural learning often links up with real-life experiences. This is where its strength lies. Religious education has to follow this approach, so as not to ignore the life situations of children. This, however, leads to the danger of limiting intercultural learning to local options. Therefore, religious education cannot do without the larger frame-work of ecumenical learning

- with its international reference

- with its dialectic of local and international approaches and options

- with its consideration of religion and religiousness

- with its reference to past and present experiences, especially in view of the potential of the ecumenical movement

- with its visionary perspective, especially the active hope of the Kingdom of God: Hope versus hopelessness 